\title{
Pengaruh Program Gemar Membaca terhadap Kemampuan Mengarang Siswa Kelas IV SD
}

\section{Hakimah Saidah}

Pendidikan Guru Sekolah Dasar Universitas PGRI Semarang Jln. Sidodadi Timur Nomor 24 Karangtempel, Semarang Timur, Semarang Email: hakimah.saidah12@gmail.com

\begin{tabular}{|c|c|}
\hline ABSTRACT & ABSTRAK \\
\hline $\begin{array}{l}\text { The reading program is another name for } \\
\text { reading literature used by SDN Bugangan } 02 \\
\text { Semarang. Implementation of the program likes } \\
\text { to read that is } 15 \text { minutes before the learning } \\
\text { activities of students reading books with the title } \\
\text { as he wishes. In this study students are given a } \\
\text { book entitled "a collection of children's stories } \\
\text { about the habit of eating healthy food". This short } \\
\text { story contains six titles of children with a theme of } \\
\text { healthy food. This theme is in accordance with } \\
\text { the 9th grade theme teacher's book. This study } \\
\text { aims to determine the effect of reading } \\
\text { programs on the ability to make students. This } \\
\text { research uses Pre-Experiment Designs with } \\
\text { quantitative approach. The sample of this } \\
\text { research is all students of grade IV SDN } \\
\text { Bugangan } 02 \text { Semarang. The results of this study } \\
\text { indicate that reading programs affect students' } \\
\text { writing ability. } \\
\text { Keywords: love to read; program, ability; } \\
\text { compose }\end{array}$ & $\begin{array}{l}\text { Program gemar membaca adalah nama lain } \\
\text { dari literasi membaca yang digunakan SDN } \\
\text { Bugangan } 02 \text { Semarang. Pelaksanaan program } \\
\text { gemar membaca yaitu } 15 \text { menit sebelum } \\
\text { kegiatan belajar mengajar, siswa membaca } \\
\text { buku dengan judul sesuai keinginannya. Pada } \\
\text { penelitian ini siswa diberi buku yang berjudul } \\
\text { "kumpulan cerpen anak tentang kebiasaan } \\
\text { memakan makanan sehat". Cerpen ini berisi } \\
\text { enam judul cerpen anak dengan tema } \\
\text { makanan sehat. Tema ini sesuai dengan buku } \\
\text { guru tema 9 kelas IV. Penelitian ini bertujuan } \\
\text { untuk mengetahui pengaruh program gemar } \\
\text { membaca terhadap kemampuan mengarang } \\
\text { siswa. Penelitian ini menggunakan Pre- } \\
\text { eksperimen Designs dengan pendekatan } \\
\text { kuantitatif. Sampel dari penelitian ini adalah } \\
\text { seluruh siswa kelas IV SDN Bugangan } 02 \\
\text { Semarang. Hasil penelitian ini menunjukkan } \\
\text { bahwa program gemar membaca } \\
\text { mempengaruhi kemampuan mengarang siswa. } \\
\text { Kata Kunci: gemar membaca; program; } \\
\text { kemampuan; mengarang }\end{array}$ \\
\hline
\end{tabular}

How to Cite: Saidah, H. (2017). Pengaruh Program Gemar Membaca terhadap Kemampuan Mengarang Siswa Kelas IV SD. Mimbar Sekolah Dasar, 4(3), 225-234. http://doi.org/10.17509/mimbar-sd.v4i3.7863.

PENDAHULUAN Berdasarkan observasi pada 7 November 2016 di kelas IV SDN Bugangan 02 Semarang kemampuan siswa dalam menulis narasi masih tergolong rendah. Hal ini terlihat dari tes mengarang cerita dengan tema "keanekaragaman budaya Indonesia". Siswa masih kesulitan menuangkan ide ke dalam cerita, meruntutkan isi cerita, memadukan kalimat dan penggunaan ejaan serta tanda baca yang kurang tepat. Terbukti siswa yang mendapat nilai $\leq 50$ sebanyak 13 siswa, nilai 51-60 sebanyak 10, 61-70 sebanyak 7 siswa dan $\geq 71$ sebanyak 4 siswa. Berdasarkan data tersebut, kemampuan mengarang siswa secara klasikal masih kurang dari batas minimum ketuntasan yang diterapkan oleh pihak sekolah yaitu 71 .

Berdasarkan kenyataan tersebut, untuk meningkatkan kemampuan mengarang 
Hakimah Saidah, Pengaruh Program Gemar Membaca terhadap Kemampuan Mengarang...

siswa diperlukan strategi khusus untuk membuat siswa lebih bersemangat dan tertarik untuk menulis sebuah karangan. Untuk menuangkan cerita kedalam tulisan tidaklah mudah. Perlu latihan secara terus menerus dan diimbangi kebiasaan membaca buku. Pada saat observasi, siswa merasa kesulitan menuangkan ide cerita dalam bentuk tulisan. Siswa membutuhkan contoh teks karangan untuk menuangkan ide cerita ke dalam tulisan. Peneliti menawarkan tindakan alternatif untuk mengatasi masalah tersebut dengan menggalakan program gemar membaca untuk mendukung daya tangkap dan imajinasi siswa.

Undang-undang Republik Indonesia Nomor 40 Tahun 2007 tentang Perpustakaan Bab II Pasal 7, menyatakan bahwa Pemerintah berkewajiban menjamin kelangsungan penyelenggaraan dan pengelolaan perpustakaan sebagai pusat sumber belajar masyarakat, menggalakkan promosi gemar membaca dan memanfaatkan perpustakaan.

Menurut An dan Raphael (Rahim, 2007) peranan guru dalam proses membaca, antara lain menciptakan pengalaman yang memperkenalkan, memelihara, atau memperluas kemampuan siswa untuk memahami teks. Hal tersebut mensyaratkan guru melaksanakan pembelajaran langsung, memodelkan, membantu meningkatkan, memfasilitasi, serta mengikutsertakan siswa dalam pembelajaran.

Program gemar membaca memang sudah terealisasi di sekolah. Akan tetapi dalam pelaksanaannya belum maksimal. Kurangnya jam untuk membaca dan banyaknya materi ajar merupakan salah satu penyebab belum maksimalnya pelaksanaan program gemar membaca ini. Ditambah lagi dengan kurangnya persediaan buku di perpustakaan. Di perpustakaan lebih banyak berisikan buku pelajaran dan sedikit buku cerita. Jika pun ada buku cerita, kebanyakan untuk usia kelas tinggi. Untuk usia kelas rendah hanya ada sedikit buku. Hal tersebut membuat siswa enggan untuk membaca di perpustakaan. Teknik membaca buku menurut Iswara (2014) dapat dilakukan dengan teknik membuka-buka buku. Keuntungan dari teknik ini dapat menguasai gambaran isi buku. Dan hal ini dapat membantu siswa untuk dapat mengembangkan menjadi ide karangan.

Pembelajaran mengarang sudah ada mulai kelas III SD, namun setiap kali siswa diminta untuk mengarang, mereka enggan untuk segera mengarang. Banyak dari mereka yang mengeluh kesusahan untuk menuangkan ide kedalam tulisan. Mengarang dianggap suatu hal yang sangat sulit bagi siswa, sebagaimana pula dinyataan oleh MS (2014) bahwa siswa masih mengalami kesulitan dalam mengaang. Walaupun mengarang tentang aktivitas sehari-hari, tetap saja 
siswa merasa sulit untuk menuliskan cerita itu.

Berdasarkan uraian yang telah dijabarkan maka peneliti membuat solusi dengan membiasakan membaca buku terutama buku cerita melalui program gemar membaca pada jam membaca yang sudah diberikan ataupun jam-jam kosong serta jam istirahat.

Tujuan penelitian adalah untuk mengetahui Pengaruh Program Gemar Membaca terhadap Kemampuan Mengarang pada Siswa kelas IV SDN Bugangan 02 Semarang.

\section{METODE}

Rancangan (Design) yang digunakan pada penelitian ini adalah Pre-eksperimen Designs dengan pendekatan kuantitatif. Bentuk desain eksperimen yang digunakan adalah menggunaan rancangan One Group Pretest Posttest Design yaitu hanya satu kelas yang digunakan sebagai subjek penelitian. Hanya ada kelas eksperimen, dan belum ada kelas kontrol yang dijadikan sebagai pembanding. Peneliti hanya membandingkan nilai pretes dan postes. Siswa diberikan perlakuan dalam kegiatan mengarang dengan menggunakan program gemar membaca.

\section{Subjek}

Dalam penelitian ini yang menjadi populasi adalah seluruh siswa SDN Bugangan 02 Semarang tahun pelajaran
2016/ 2017. Sampel pada penelitian ini adalah seluruh siswa kelas IV SDN Bugangan 02 Semarang tahun pelajaran 2016/2017.

\section{Waktu dan tempat}

Penelitian ini bertempat di SDN Bugangan 02 Semarang yang beralamat di Jl. Barito, Rejosari, Semarang Timur, Semarang. Penelitian dilaksanakan pada semester II selama satu minggu dengan 1 kali pretes di awal dan postes di akhir pada minggu pertama bulan Maret 2017.

\section{Teknik Pengumpulan Data}

Penelitian ini menggunakan teknik pengumpulan data berupa tes, dengan jenis tes esai. Tes esai diberikan untuk mengetahui kemampuan mengarang siswa. Tes esai diberikan pada saat Pretes dan Postes. Pretes sebagai tes awal digunakan untuk mengetahui kemampuan mengarang siswa sebelum menggunakan program gemar membaca. Postes sebagai tes awal digunakan untuk mengetahui kemampuan mengarang siswa sebelum menggunakan program gemar membaca.

\section{Teknik Pengambilan Data}

Pada penelitian ini data diambil dari perhitungan uji hipotesis dan uji normalitas. Uji normalitas dihitung 2 kali yaitu normalitas postes dan normalitas pretes. Uji normalitas ini digunakan untuk mengetahui apakah aktivitas belajar siswa pada suatu kelas berdistribusi normal atau 
Hakimah Saidah, Pengaruh Program Gemar Membaca terhadap Kemampuan Mengarang...

tidak. Hipotesis statistik yang akan diuji yaitu:

$H_{\circ}$ : sampel berasal dari populasi yang berdistribbusi normal.

$\mathrm{H}_{\mathrm{a}}$ : sampel berasal dari populasi yang berdistribusi tidak normal.

Uji hipotesis digunakan untuk menganalisis hasil penelitian yang menggunakan one group pretest posttest design dengan menggunakan rumus sebagai berikut (Arikunto, 2010, p.349).

Rumus uji † sebagai berikut:

$t=\frac{M d}{\sqrt{\frac{\sum x^{2} d}{N(N-1)}}}$

\section{HASIL}

Ada Beberapa tahap yang dilakukan peneliti pada proses analisis data. Proses yang pertama adalah melakukan analisis data kuantitatif meliputi uji normalitas untuk mengetahui tingkat kenormalan distribusi nilai data pretes dan postes. Uji normalitas menggunakan uji liliefors, sedangkan uji hipotesis penelitian menggunakan uji †.

\section{Uji Normalitas Sebelum Perlakuan}

Uji normalitas pretes digunakan untuk mengetahui data yang diperoleh, maka dilakukan dengan menggunakan uji liliefors pada taraf signifikan $5 \%$. Kriteria dalam uji normalitas ini adalah:

Lo $<$ Ltabel maka populasi distribusi normal Lo > Ltabel maka populasi tidak distribusi normal
Tabel 1. Hasil Uji Lilifors Data sebelum Perlakuan

\begin{tabular}{|l|l|c|c|l|}
\hline Data & $\mathrm{N}$ & Lo & Ltabel & Kesimpulan \\
\hline Pretes & 34 & 0,0225 & 0,151948 & $\begin{array}{l}\text { Distribusi } \\
\text { Normal }\end{array}$ \\
\hline
\end{tabular}

Dari tabel 1 terlihat bahwa Lo <_Ltabel pada taraf $5 \%$ dan $\mathrm{N}=34$, maka Ho diterima. Jadi, data pretes tersebut berdistribusi normal. Adapun langkah-langkah perhitungan secara lengkap sebagai berikut:

Mencari rata-rata

$$
\begin{aligned}
x & =\frac{\sum x}{n} \\
& =\frac{1620}{34} \\
& =47,647
\end{aligned}
$$

Mencari simpangan baku

$$
S=\sqrt{\frac{\sum(x-\mathrm{X})^{2}}{n-1}}
$$

$=\sqrt{\frac{\sum(47,647-x)^{2}}{33}}$

$=13,21359$

Mencari $\mathrm{Zi}_{\mathrm{i}}$

$$
\begin{aligned}
\mathrm{Zi} & =\frac{x-x}{s} \\
& =\frac{65-47,64706}{13,21359} \\
& =1.3132646011
\end{aligned}
$$

Perhitungan $Z_{i}$ diatas dapat diketahui $Z_{\text {tabel }}$ $=0,4049$ karena hasilnya positif, maka $F\left(Z_{i}\right)$

$$
\begin{aligned}
=0,5 & +0,4049=0,9049 \\
\mathrm{~S}(\mathrm{Zi}) & =\frac{(\text { banyak } z 1, z 2, z 3 \ldots \ldots \ldots}{n} \\
& =\frac{30}{34} \\
& =0,8824
\end{aligned}
$$

Hitung selisih $\mid \mathrm{F}\left(\mathrm{Z}_{\mathrm{i}}\right)$ - $\mathrm{S}(\mathrm{Zi}) \mid$ 


$$
\begin{aligned}
& F\left(Z_{i}\right)-S(Z i) \\
& 0,9049-0,8824=0,0225
\end{aligned}
$$

Untuk menolak dan menerima hipotesis, bandingkan Lo dengan nilai kritis $L$ untuk uji liliefors dengan taraf signifikan $5 \%$. Jika $L_{0}<$ Ltabel maka $\mathrm{H}_{\circ}$ diterima, artinya data berdistribusi normal. Hasil perhitungan yang telah dilakukan oleh peneliti diperoleh Lo sebesar 0,0225 dan Ltabel sebesar 0,151948 . Jadi $L_{0}<$ Ltabel dan $H_{\circ}$ diterima artinya berdistribusi normal.

\section{Uji Normalitas Sesudah perlakuan}

Uji normalitas postes digunakan untuk mengetahui data yang diperoleh, maka dilakukan dengan menggunakan uji liliefors pada taraf signifikan $5 \%$. Kriteria dalam uji normalitas ini adalah:

Lo $<$ Ltabel maka populasi distribusi normal

Lo > Ltabel maka populasi tidak distribusi normal

\section{Tabel 2. Hasil Uji Lilifors Data sesudah Perlakuan}

\begin{tabular}{|c|c|c|c|c|}
\hline Data & $\mathrm{N}$ & Lo & Ltabel & Kesimpulan \\
\hline $\begin{array}{c}\text { Poste } \\
\text { s }\end{array}$ & 34 & 0,0427 & 0,151948 & $\begin{array}{c}\text { Distribusi } \\
\text { Normal }\end{array}$ \\
\hline
\end{tabular}

Dari tabel 2 terlihat bahwa Lo <_Ltabel pada taraf $5 \%$ dan $\mathrm{N}=34$, maka Ho diterima. Jadi, data postes tersebut berdistribusi normal. Adapun langkah-langkah perhitungan secara lengkap sebagai berikut:

Mencari rata-rata

$$
\begin{aligned}
x & =\frac{\sum x}{n} \\
& =\frac{2210}{34} \\
& =65
\end{aligned}
$$

Mencari simpangan baku

$$
\begin{aligned}
S & =\sqrt{\frac{\sum(x-x)^{2}}{n-1}} \\
& =\sqrt{\frac{494.1651}{34-1}} \\
& =14,9747
\end{aligned}
$$

Mencari $\mathrm{Z}_{\mathrm{i}}$

$$
\begin{aligned}
\mathrm{Zi} & =\frac{x-x}{s} \\
& =\frac{75-65}{14,9747} \\
& =0,6677
\end{aligned}
$$

Perhitungan $Z_{i}$ diatas dapat diketahui Z Zabel $=0,0427$ karena hasilnya positif, maka $F\left(Z_{i}\right)$ $=0,5+0,2486=0,7486$

$$
\begin{aligned}
\mathrm{S}(\mathrm{Zi}) & =\frac{(\text { banyak } z 1, z 2, z 3 \ldots \ldots \ldots}{n} \\
& =\frac{24}{34} \\
& =0,7059
\end{aligned}
$$

Hitung selisih $\left|F\left(Z_{i}\right)-S(Z i)\right|$

$F\left(Z_{i}\right)-S(Z i)$

$0,7486-0,7059=0,0427$

(Sudjana, 2002, p. 92)

Untuk menolak dan menerima hipotesis, bandingkan $L o$ dengan nilai kritis $L$ untuk uji liliefors dengan taraf signifikan $5 \%$. Jika $L_{0}<$ Ltabel maka $H_{\circ}$ diterima, artinya data berdistribusi normal. Hasil perhitungan yang telah dilakukan oleh peneliti diperoleh Lo sebesar 0,0427 dan Ltabel sebesar 0,15195. Jadi $L_{0}<$ Ltabel dan $\mathrm{H}_{\circ}$ diterima artinya berdistribusi normal.

Uji normalitas mengarang dengan menggunakan program gemar membaca terlebih dahulu untuk mengetahui data yang diperoleh normal atau tidak. Untuk 
Hakimah Saidah, Pengaruh Program Gemar Membaca terhadap Kemampuan Mengarang...

mengetahui normalitas data yang diperoleh, maka dilakukan dengan menggunakan uji hipotesis, pada taraf signifikan $5 \%$. Kriteria dalam uji normaitas ini adalah:

Lo $<$ Ltabel maka populasi distribusi normal Lo > Ltabel maka populasi tidak distribusi normal

Tabel 3. Hasil Uji Normalitas Pretes dan Postes

\begin{tabular}{|l|l|l|l|l|}
\hline $\begin{array}{l}\text { Pelaksana } \\
\text { an }\end{array}$ & $\mathrm{N}$ & Lhitung & Ltabel & $\begin{array}{l}\text { Kesimpul } \\
\text { an }\end{array}$ \\
\hline $\begin{array}{l}\text { Tanpa } \\
\text { Perlakuan }\end{array}$ & 34 & 0,0225 & 0,151948 & $\begin{array}{l}\text { Distribusi } \\
\text { Normal }\end{array}$ \\
\hline $\begin{array}{l}\text { Melaksana } \\
\text { kan } \\
\text { program } \\
\text { gemar } \\
\text { membaca }\end{array}$ & 34 & 0,0427 & 0,151948 & $\begin{array}{l}\text { Distribusi } \\
\text { Normal }\end{array}$ \\
\hline
\end{tabular}

Dari tabel 3 terlihat bahwa untuk proses pembelajaran tanpa perlakuan diperoleh Lo dari nilai $\mid F\left(Z_{i}\right)$ - S(Zi) | yang paling besar, yaitu 0,0225 . Kriteria pengujian $\mathrm{H}_{\circ}$ diterima jika Lo $<$ Ltabel untuk $N_{1}=34$ pada taraf nyata $5 \%$ diperoleh 0,151948 . Pelaksanaan program gemar membaca diperoleh Lo dari nilai $\mid F\left(Z_{i}\right)$ - $S(Z i) \mid$ yang paling besar yaitu 0,0427 . Kriteria pengujian $\mathrm{H}_{\circ}$ diterima jika Lo $<$ Ltabel untuk $N_{1}=34$ pada taraf nyata $5 \%$ diperoleh 0,151948 . Pada tabel 4 disimpulkan bahwa $\mathrm{H}_{\circ}$ diterima. Jadi untuk data tanpa perlakuan maupun data yang sudah diberi perlakuan berdistribusi normal.

\section{Uji Hipotesis}

Pada hasil perhitungan persyaratan data menunjukkan bahwa data berdistribusi normal. Selanjutnya untuk menguji perbedaan nilai postes dan pretes menggunakan uji t-test satu pihak ini dilakukan untuk mengetahui adanya perbedaan pada kemampuan akhir setelah siswa diberi perlakuan, dengan harapan akan terjadi perbedaan pada kemampuan akhir karena adanya pengaruh perlakuan. Peneliti menggunakan rumus t-test untuk mengetahui terjadinya perbedaan perlakuan tersebut dengan hipotesis kemampuan akhir sebagai berikut:

$H_{0}: \mu_{1}<\mu_{2}=$ tidak ada perbedaan hasil karangan antara postes dan pretes

$H_{a}: \mu_{1}>\mu_{2}=$ ada perbedaan hasil karangan antara postes dan pretes

Berdasarkan data kemampuan menulis karangan narasi hasil postes dan pretes, dapat menggunakan uji hipotesis untuk membuktikan pengaruh program gemar membaca terhadap kemampuan mengaranng siswa kelas IV SDN Bugangan 02 Semarang. Adapun langkah-langkah perhitungan sebagai berikut:

$$
\begin{aligned}
t & =\frac{M d}{\sqrt{\frac{\sum x^{2} d}{N(N-1)}}} \\
& =\frac{17,35294}{\sqrt{\frac{711,7647}{34(34-1)}}} \\
& =\frac{17,35294}{\sqrt{\frac{17,35294}{1.122}}} \\
& =\frac{17,35294}{\sqrt{0,634371}} \\
& =\frac{17,35294}{0,796474} \\
& =21,78731
\end{aligned}
$$

Hasil perhitungan thiung $=21,78731$ kemudian dibandingkan dengan tabel 
dengan taraf signifikan $5 \%$ dan dk $=\mathrm{n}-1=$ 34-1 = 33, maka tabel 1,692 sehingga dapat diketahui bahwa thiung $=21,78731>t_{\text {tabel }}=$ 1,692 oleh karena itu pengujian hipotesis diterima, dapat disimpulkan bahwa program gemar membaca berpengaruh terhadap kemampuan mengarang siswa kelas IV SDN Bugangan 02 Semarang. Hasil perhitungan dapat disajikan dalam tabel 4 sebagai berikut:

Tabel 4. Hasil Uji Hipotesis Pretes dan Postes

\begin{tabular}{|c|c|c|c|c|l|}
\hline Pelaksanaan & Rata-rata & $\mathrm{N}$ & Lo & Ltabel & Kesimpulan \\
\hline Pretes & 47.64706 & 34 & 21,78731 & 1,692 & Signifikan \\
\hline Postes & 65 & & & & \\
\hline
\end{tabular}

\section{PEMBAHASAN}

Penelitian ini merupakan penelitian untuk mengetahui pengaruh program gemar membaca terhadap kemampuan mengarang siswa sesuai dengan rumusan masalah yang telah di tentukan. Peneliti menganalisis hasil prestest dan postes mengarang. Adapun acuan yang digunakan penelitian dalam menganalisis hasil tes adalah menggunakan kriteria penilaian mengarang pada buku guru tema 9 serta kategori peneitian prestest dan postes kemampuan mengarang yang diambil dari buku karangan Djiwandono (2011). Penilaian berdasarkan pada "Panduan Teknis Penilaian Kurkulum 2013 di Sekolah Dasar". Panduan ini yang digunakan guru di SDN Bugangan 02 Semarang.

$$
N=\frac{\text { jumlah skor yang diperoleh }}{\text { skor maksimal }} \times 100
$$

Tabel 5. Skor Penilaian Mengarang

\begin{tabular}{|c|c|c|}
\hline No & Rentang & Keterangan \\
\hline 1 & $86-100$ & Sangat Baik (A) \\
\hline 2 & $71-85$ & Baik (B) \\
\hline 3 & $56-70$ & Cukup (C) \\
\hline 4 & $\leq 55$ & Perlu Bimbingan (D) \\
\hline
\end{tabular}

Rentang nilai sesuai panduan teknis penilaian kurikulum 2013 di sekolah dasar yang di buat oleh Kementrian Pendidikan dan Kebudayaan Direktorat Jendral Pendidikan Dasar (2013). Panduan ini digunakan SDN Bugangan 02 Semarang untuk mengambil nilai setiap mata pelajaran.

Program gemar membaca adalah nama lain dari literasi membaca. Pada SDN Bugangan 02 Semarang literasi membaca di namakan program gemar membaca untuk mengakrabkan Gerakan Literasi Sekolah (GSL) yang digalakkan oleh pemerintah. Direktorat Jendral Pendidikan Dasar dan Menengah (Tt) menyatakan bahwa GSL bertujuan Menumbuhkembangkan budi pekerti peserta didik melalui pembudayaan ekosistem literasi sekolah yang diwujudkan dalam Gerakan Literasi Sekolah agar mereka menjadi pembelajar sepanjang hayat. Secara khusus tujuan dari GSL menurut Direktorat Jenderal Pendidikan Dasar dan Menengah (2016) adalah Menumbuhkembangkan budaya literasi 
Hakimah Saidah, Pengaruh Program Gemar Membaca terhadap Kemampuan Mengarang...

membaca dan menulis siswa di sekolah. Pelaksanaan program gemar membaca sama seperti literasi membaca pada umumnya, sebagaimana yang tertuang dalam Permendikbud No. 23 Tahun 2015 yaitu penumbuhan minat baca melalui kegiatan 15 menit membaca. Pada penelitian ini siswa diberi buku yang berjudul "kumpulan cerpen anak tentang kebiasaan memakan makanan sehat". Cerpen ini berisi enam judul cerpen anak dengan tema makanan sehat. Tema ini sesuai dengan buku guru tema 9 kelas IV (Kemendikbud, 2014).

Data menunjukkan ada perbedaan antara kemampan mengarang siswa tanpa penerapan program gemar membaca dengan kemampuan mengarang siswa dengan penerapan program gemar membaca. Hal ini dibuktikan dengan meningkatnya ratarata nilai postes di banding nilai pretes. untuk mengetahui perbedaan rata-rata antara keduanya menggunakan uji t-test.

Mengunakan uji t-test yaitu menbandingkan rata-rata nilai postes dan pretes dengan jumlah $\mathrm{n}=34$ siswa diperoleh thitung $=21,78731$. Dengan taraf signifikan $5 \% \mathrm{dk}=33$ diperoleh t tabel $=1,692$ maka di peroleh thitung $=21,7873>t_{\text {tabel }}=$ 1,692 sehingga $\mathrm{H}_{0}$ ditolak dan $\mathrm{H}_{\mathrm{a}}$ diterima artinya terdapat pengaruh yang signifikan program gemar membaca terhadap kekampuan mengarang siswa kelas IV SDN Bugangan 02 Semarang.
Berdasarkan perhitungan statistik, diperoleh thitung sebesar 21,78731 yang harus di bandingkan dengan ttabel. Harga thitung dapat diketahui dari derajat kebebasan $(\mathrm{dk})=33$ pada taraf signifikan $5 \%$ sebesar 1,692. Hal ini menunjukkan bahwa thitung $=21,78731>t_{\text {tabel }}=1,692$. Artinya terdapat pengaruh program gemar membaca terhadap kemampuan mengarang pada siswa. Sesuai dengan kompetensi dasar 4.4 menyajikan teks petualangan tentang lingkungan dan sumber daya alam secara mandiri dalam teks bahasa Indonesia lisan dan tulis dengan memilih dan memilah kosakata baku. Sehingga $\mathrm{Ha}_{a}$ diterima dan data yang diperoleh sangat signifikan. Berdasarkan uraian di atas, dapat disimpulkan bahwa program gemar membaca berpengaruh terhadap kemampuan mengarang siswa kelas IV SDN Bugangan 02 Semarang.

Hal ini sesuai dengan teori behavioristik dimana perubahan tingkah laku yang dapat diamati, diukur dan dinilai secara konkret. Pada penelitian ini perubahan tingkah laku berupa kebiasaan membaca yang terjadi dalam diri siswa. Pada mulanya siswa enggan untuk membaca buku, akan tetapi dengan pembiasaan membaca melalui program gemar membaca siswa mulai terbiasa membaca buku. Artinya, program gemar membaca berpengaruh terhadap tingkah laku siswa yaitu siswa terbiasa membaca buku. Behaviorisme berkaitan dengan kelakuan manusia dengan adanya stimulus dan 
respon. Pada penelitian ini siswa diberi stimulus program gemar membaca, sedangkan respon siswa melaksanakan program gemar membaca.

Hal tersebut dapat diperkuat pada analisis data yang dilakukan menggunakan uji ttest. Pada uji t-test dapat dilihat bahwa $t_{\text {tabel }}<$ thitung.. hal ini menunjukkan bahwa program gemar membaca berpengaruh pada kemampuan mengarang siswa. Pada aliran behavioristic (Syah, 2003) belajar pada hakikatnya adalah pembentukan asosiasi antara kesan yang ditangkap panca indra dengan kecenderungan untuk bertindak atau hubungan antara stimulus dan respon. Pada penelitian pemberian buku kumpulan cerita anak pada program gemar membaca berkesan dalam diri siswa sehingga dapat meningkatkan kemampuan mengarang siswa.

\section{SIMPULAN}

Berdasarkan hasil penelitian yang dilaksanakan di SDN Bugangan 02 Semarang dapat disimpulkan bahwa terdapat pengaruh pada program gemar membaca terhadap kemampuan mengarang siswa kelas IV SDN Bugangan 02 Semarang. Hal ini dapat dilihat dari rata-rata nilai pretes lebih rendah dibanding nilai postes. Hasil rata-rata pretes sejumlah 47,647 sedangkan ratarata postes sejumlah 65, sehingga dapat disimpulkan bahwa rata-rata pada kelas postes lebih tinggi dari pada pretes. Diperkuat dengan hasil uji hipotesis menggunakan uji-† diperoleh thitung $>$ tabel. Hasil perhitungan uji- $\dagger$ diperoleh thitung sebesar 21,78731 sedangkan tabel $=1,692$ $(21,78731>1,692)$. Jika $\mathrm{H}_{0}$ ditolak dan $\mathrm{H}_{\mathrm{a}}$ diterima artinya terdapat pengaruh yang signifikan program gemar membaca terhadap kemampuan mengarang siswa kelas IV SDN Bugangan 02 Semarang.

\section{REFERENSI}

Arikunto, Suharsimi. 2010. Prosedur Penelitian. Jakarta: Rineka Cipta.

Direktorat Jendral Pendidikan Dasar dan Menengah Kementrian Pendidikan dan Kebudayaan. 2016. Desain Induk Gerakan Literasi Sekolah. Jakarta: Kemendikbud.

Direktorat Pendidikan Dasar dan Mengengah, (Tt). Buku Saku Gerakan Literasi Sekolah: Menumbuhkan Budaya Literasi di Sekolah. Jakarta: Kemendikbud.

Djiwandono, S. (2011). Tes Bahasa Pegangan Bagi Pengajar Bahasa. Jakarta: PT Indeks.

Iswara, P. (2014). Teknik Membaca Buku Dengan Membuka-Buka Buku. Mimbar Sekolah.

doi:http://dx.doi.org/10.17509/mimbarsd.vlil.859
Kementerian Pendidikan Dan Kebudayaan Direktorat Jenderal Pendidikan Dasar Direktorat Pembinaan Sekolah Dasar. (2013). Panduan Teknis Penilaian Di Sekolah Dasar. Jakarta: Kemendikbud.

Kementrian Pendidikan dan Kebudayaan Republik Indonesia. (2014). BukU Tematik Terpadu Kurikulum 2013 Tema 9 Makananku Sehat dan Bergizi: Buku Guru SD/MI Kelas IV. Jakarta: Kemendikbud.

MS, Z. (2014). Pendekatan Kontekstual Dalam Pembelajaran Menulis Di Sekolah Dasar (Action Research Di 
Hakimah Saidah, Pengaruh Program Gemar Membaca terhadap Kemampuan Mengarang...

Kelas Tinggi Sekolah Dasar). Mimbar Sekolah Dasar, 1(1), 83-91. doi:http://dx.doi.org/10.17509/mimbarsd.v1il.1363

Peraturan Menteri Pendidikan Dan Kebudayaan Republik Indonesia Nomor 23 Tahun 2015 Tentang Penumbuhan Budi Pekerti

Rahim, F. (2007). Pengajaran Membaca di Sekolah Dasar. Jakarta: Bumi Aksara.

Sudjana, 2002. Metode Statistika. Bandung: Tarsito.

Syah, M. (2003). Psikologi Belajar. Jakarta: RajaGrafindo Persada 